\title{
Struktur Komunitas Uca Sp Di Kawasan Teluk Benoa Pada Karakteristik Substrat Yang Berbeda
}

\author{
Ni Wayan Loviasari a*, Abd. Rahman As-Syakur a, Elok Faiqoh a, \\ I Gusti Ngurah Putra Dirgayusa a, Dwi Budi Wiyanto a \\ a Program Studi Ilmu Kelautan, Fakultas Kelautan dan Perikanan, Universitas Udayana, Kampus UNUD Bukit Jimbaran, Bali 80361, Indonesia \\ *Penulis koresponden. Tel.: +62-81-239-677-254 \\ Alamate-mail: ririloviasari@yahoo.com
}

Diterima (received) 20 Juli 2017; disetujui (accepted) 11 September 2017; tersedia secara online (available online) 13 September

\begin{abstract}
The mangrove ecosystem is home to a variety of fauna, ranging from water animals to primates, as a breeding ground for a variety of aquatic animals such as fish, crustaceans, crabs and mollusks, as well as a place to feed a number of wildlife such as reptiles and mammals. Uca sp is one of the fauna that utilizes and helps mangrove in its ecological balance. This research was conducted on 3 mangrove areas with the purpose of knowing the types and structure of Uca sp community on different substrate characteristics, where in Mertasari mangrove have the type of sandy substrate, Muara Waduk Nusa Dua Denpasar has kind of sandy loam substrate and Tanjung Benoa has kind sandy substrate. The sampling time was conducted in December 2016 when the lowest tide of the month. Determination of stations taken at each research location (station) using purposive sampling method. From the results of the study found Uca sp as many as 5 types, namely Uca cryptica, Uca dussumieri, Uca rosea, Uca cryptica and Uca crassipes. The highest density of Uca sp that is at station 2 located in Muara Waduk Nusa Dua Denpasar is 52,75 ind $/ \mathrm{m}^{2}$ and lowest at station 3 in Tanjung Benoa get 32,25 ind $/ \mathrm{m}^{2}$. The index values of the diversity of the three research stations are categorized into low diversity. In all three research stations categorized into uniformity index with depressed community or low uniformity. Based on the calculation on the three stations have a high dominance index.
\end{abstract}

Keywords: Uca sp; community structure; substrate

\begin{abstract}
Abstrak
Ekosistem mangrove merupakan tempat tinggal berbagai jenis fauna, mulai dari satwa air hingga primata, sebagai tempat berkembang biak berbagai satwa air seperti ikan, udang-udangan, kepiting dan moluska, selain itu menjadi tempat mencari makan sejumlah satwa liar seperti reptil dan mamalia. Uca sp merupakan salah satu fauna yang memanfaatkan dan membantu mangrove dalam keseimbangan ekologinya. Penelitian ini dilakukan pada 3 kawasan mangrove dengan tujuan mengetahui jenis-jenis dan struktur komunitas Uca sp pada karakteristik substrat yang berbeda, dimana pada mangrove Mertasari memiliki jenis substrat pasir berlempung, Muara Waduk Nusa Dua Kota Denpasar memiliki jenis substrat lempung berpasir dan Tanjung Benoa memiliki jenis substrat berpasir. Waktu pengambilan sampel dilakukan pada bulan Desember 2016 saat surut terendah di bulan tersebut. Penentuan stasiun yang diambil pada setiap lokasi penelitian (stasiun) menggunakan metode purposive sampling. Dari hasil studi ditemukan Uca sp sebanyak 5 jenis, yaitu Uca cryptica, Uca dussumieri, Uca rosea, Uca cryptica dan Uca crassipes. Kepadatan Uca sp tertinggi yaitu pada stasiun 2 yang terletak di Muara Waduk Nusa Dua Kota Denpasar didapatkan $52,75 \mathrm{ind} / \mathrm{m}^{2}$ dan terendah pada stasiun 3 yang berada di Tanjung Benoa didapatkan 32,25 ind $/ \mathrm{m}^{2}$. Nilai indeks keanekaragaman ketiga stasiun penelitian dikategorikan kedalam keanekaragaman rendah. Pada ketiga stasiun penelitian dikategorikan kedalam indeks keseragaman dengan komunitas tertekan atau keseragaman rendah. Berdasarkan perhitungan pada ketiga stasiun tersebut mempunyai indeks dominansi tinggi.
\end{abstract}

Kata Kunci: Uca sp; struktur komunitas; substrat 


\section{Pendahuluan}

Indonesia merupakan negara yang mempunyai hutan mangrove (hutan bakau) paling luas di dunia. Ekosistem hutan mangrove bersifat khas, baik karena adanya pelumpuran yang mengakibatkan kurangnya aerasi tanah, salinitas tanahnya yang tinggi, serta mengalami daur penggenangan oleh pasang-surut air laut (Pratiwi, 2009).

Secara administratif Teluk Benoa terletak di perairan lintas Kabupaten/Kota yaitu Kota Denpasar dan Kabupaten Badung. Wilayah Teluk Benoa termasuk kedalam tiga kecamatan yaitu Denpasar Selatan, Kuta dan Kuta Selatan. Hutan mangrove bagian selatan Bali terbentang disepanjang pesisir, mulai Pantai Sanur sampai dengan Tanjung Benoa. Hutan mangrove tersebut memiliki karakteristik substrat dan kondisi wilayah yang berbeda-beda, seperti misalnya kawasan Mangrove Pantai Mertasari, Muara Waduk Nusa Dua Kota Denpasar dan Tanjung Benoa.

Ekosistem mangrove merupakan tempat tinggal berbagai jenis fauna, mulai dari satwa air hingga primata, sebagai tempat berkembang biak berbagai satwa air seperti ikan, udang-udangan, kepiting dan moluska, selain itu menjadi tempat mencari makan sejumlah satwa liar seperti reptil dan mamalia. Fauna yang berasosiasi dengan hutan mangrove bukan hanya memanfaatkan mangrove saja tetapi juga membantu dalam menjaga keseimbangan ekologi (Majid I., et. al., 2016).

Husnah et. al (2017), menyatakan di seluruh dunia terdapat lebih dari 1000 spesies kepiting yang dikelompokkan ke dalam 50 famili. Sebagian besar kepiting hidup di laut, tersebar di seluruh lautan mulai dari zona supratidal hingga di dasar laut yang paling dalam. Ada 275 spesies dari 6 famili Brachyura yang hidup di ekosistem mangrove yaitu Geocarcinidae, Xanthidae, Portunidae, Ocypopidae, Grapsidae, dan Myctiridae. Komposisi fauna makrobentik pada hutan mangrove bermacam-macam diantaranya moluska dan kepiting yang merupakan spesies paling menonjol (Faiqoh et al., 2016). Fauna ini mempunyai peranan utama dalam menghancurkan bahan organik, yang selanjutnya dipermudah oleh mikroflora, yang akhirnya melepaskan rangkaian unsur hara (Rauf, 2016). Kepiting pemakan detritus yang menghancurkan serasah pada lingkungan hutan mangrove adalah spesies khas dari genus Sesarma dan Cardisoma. Sedangkan kepiting dari spesies Uca dan ikan tembakul (Macrophthalmus) biasanya mengekstraksi makanannya dari sedimen, sedangkan kepiting bakau (Scylla serrata) sebagai "Scavenger". Kelompok moluska di lingkungan mangrove ini bersifat "filter feeder" yang didominasi oleh gastropoda. Oleh karena itu, moluska dan kepiting ini memegang peranan ekologis yang penting pada ekosistem mangrove, selain itu juga berperan dalam mineralisasi, mengubah balik bahan organik dalam perairan yang dijadikan sebagai ukuran produktivitas dan kualitas suatu perairan (Hamidy, 2010).

Uca sp merupakan salah satu fauna yang memanfaatkan mangrove dan membantu mangrove dalam keseimbangan ekologinya (Lailvaux et al., 2009). Cara makan Uca sp dengan memakan detritus organik di lumpur (Deposit Feeder) yang mampu menjaga kestabilan unsur hara, kelangsungan siklus karbon dan mempertahankan kondisi aerob sehingga keseimbangan ekologi mangrove akan terjaga (Mulyanto and Umi, 2017). Selain itu, keberadaan Uca $s p$ dapat digunakan sebagai indikator kondisi substrat hutan mangrove yang mengindikasikan ekosistem mengrove tersebut dalam keadaan baik dan subur (Pratiwi, 2009). Uca sp hidup di mangrove dengan karakteristik substrat berlumpur dan juga substrat berpasir, dengan cara membuat liang sebagai tempat berlindung, berkembang biak dan makan. Aktivitas membuat liang membantu sirkulasi materi organik dari lapisan bawah ke atas sehingga tidak terjadi akumulasi mineral yang berpotensi terjadinya fermentasi. Banyaknya liang yang terbentuk menjadi pori-pori yang dapat meningkatkan aerasi sedimen. Maka dapat dikatakan bahwa semakin besar populasi pada jumlah tertentu maka kondisi lingkungannya akan baik. Kondisi ini memberikan pengaruh yang baik terhadap pertumbuhan vegetasi mangrove (Warsidi, 2017).

Populasi Uca lebih besar pada substrat yang padat dibandingkan substrat yang lunak. Substrat yang padat memberikan konstruksi yang lebih kuat sehingga lebih aman bagi Uca sp untuk hidup. Lokasi dengan substrat sangat lunak dan berair masih ditemukan Uca dalam jumlah yang cukup besar karena di sekitar daerah tersebut banyak dijumpai struktur keras yang dijadikan penahan liang (Murniati, 2010). 
Penelitian tentang Kepadatan Kepiting Biola (Uca spp) Jantan dan Betina telah dilakukan oleh Hamidah et.al. (2014) dan Supraygogi et.al. (2014) di Desa Tungkal I Tanjung Jabung Barat. Namun di daerah Bali belum ada yang melakukan penelitian tentang struktur komunitas Uca sp, khususnya di kawasan mangrove Teluk Benoa. Oleh karena itu, penelitian tentang Uca $s p$ di Bali perlu dilakukan. Diharapkan dengan dilakukannya penelitian mengenai struktur komunitas Uca $s p$ di Kawasan Teluk Benoa pada karakteristik substrat yang berbeda dapat menjadi informasi dasar bagi peneliti, komunitas pecinta lingkungan dan pemerintah setempat untuk melakukan pengelolaan yang tepat terhadap keberadaan Uca sp dan ekosistem mangrove di kawasan Teluk Benoa, Bali. Adapun tujuan dari penelitian ini, yaitu mengetahui jenis-jenis dan struktur komunitas kepiting biola (Uca $s p$ ) yang terdapat di 3 kawasan mangrove yang berbeda.

\section{Metode Penelitian}

\subsection{Waktu dan Tempat Penelitian}

Penelitian mengenai struktur komunitas Uca $s p$ dilakukan pada bulan Desember tahun 2016. Penelitian dilakukan pada saat surut terendah dengan tujuan untuk mempermudah pengambilan data ataupun sampel Uca sp.

Penelitian mengenai struktur komunitas Uca $s p$ dilakukan pada 3 tempat yaitu di kawasan Mangrove Mertasari Waduk Muara Nusa Dua Kota Denpasar dan Tanjung Benoa. Penentuan stasiun yang diambil pada setiap tempat penelitian menggunakan metode purposive sampling, yaitu pengambilan data yang dilakukan berdasarkan pertimbangan serta tujuan tertentu. Pada penelitian ini, penentuan stasiun pengamatan didasarkan pada karakteristik substrat pada masing-masing kawasan Mangrove. Mertasari dipilih karena memiliki jenis substrat pasir berlempung, Waduk Muara Nusa Dua Kota Denpasar memiliki jenis substrat lempung berpasir, sedangkan Tanjung Benoa memiliki jenis substrat berpasir. Lokasi penelitian dapat dilihat pada Gambar 1.

\subsection{Alat dan Bahan}

Alat dan bahan merupakan sarana yang digunakan sebagai penunjang pengambilan data

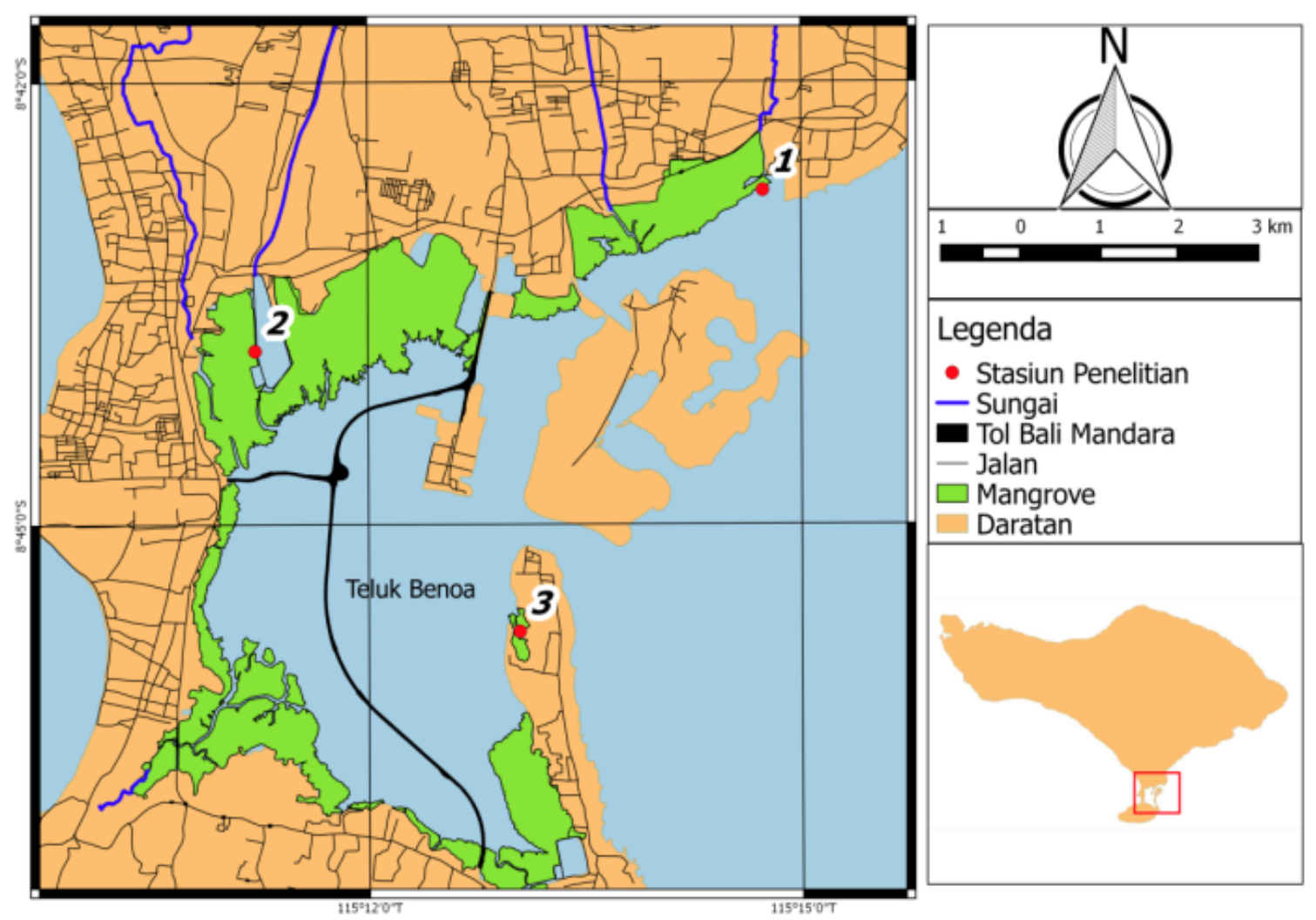

Gambar 1. Lokasi Penelitian 
maupun sampel. Adapun alat dan bahan yang digunakan untuk penelitian (Tabel 1 dan Tabel 2).

Tabel 1

Alat Penelitian

\begin{tabular}{ll}
\hline Nama Alat & Kegunaan \\
\hline Meteran & Mengukur jarak antar stasiun/plot \\
Plastik & Menyimpan sampel substrat \\
Alat tulis & Mencatat data \\
Transek $(1 \times 1)$ & $\begin{array}{l}\text { Menentukan batasan sampel yang } \\
\text { akan diambil }\end{array}$ \\
Buku Identifikasi & Mengidentifikasi jenis kepiting \\
Kepiting & Mengambil kepiting yang ada di \\
Sekop & lubang dan mengambil contoh \\
& substrat \\
GPS(Global Possitioning & Menentukan titik koordinat/ letak \\
System $)$ & stasiun \\
Kertas Label & Menandai sampel \\
Toples & Menyimpan sampel Uca \\
Kamera & Mendokumentasi penelitian \\
Pinset & Mengambil sampel Uca \\
Glove & Melindungi tangan \\
Nampan & Tempat untuk menaruh sampel \\
& Uca yang akan diamati \\
Tissu & Membersihkan alat \\
Timbangan & Menimbang substrat \\
\hline
\end{tabular}

Tabel 2

Bahan Penelitian

\begin{tabular}{ll}
\hline Nama Bahan & Kegunaan \\
\hline Formalin & Mengawetkan sampel Uca \\
Sampel Uca & Sampel yang akan diamati \\
Substrat & Parameter pendukung \\
\hline
\end{tabular}

\subsection{Metode Pengumpulan Data}

Penelitian ini terdapat 3 stasiun pengambilan sampel Uca sp, dimana setiap stasiun terdiri dari 4 sub-stasiun. Stasiun 1 di kawasan Mangrove Mertasari terdapat sub-stasiun 1 sampai 4. Stasiun 2 di Waduk Muara Nusa Dua Kota Denpasar terdapat sub-stasiun 5 sampai 8 . Stasiun 3 di Tanjung Benoa terdapat sub-stasiun 9 sampai 12 . Sub-stasiun ditentukan berdasarkan metode random sampling, yaitu untuk mencari titik substasiun yang memiliki kerapatan $U c a s p$ yang tinggi.Adapun gambaran titik stasiun dan substasiun pengambilan data yang dapat dilihat pada Gambar 2.

\subsubsection{Pengambilan Sampel Uca sp}

Pengambilan sampel dilakukan pada surut terendah. Pada stasiun yang sudah ditentukan sebelumnya, dipasang transek berukuran $1 \mathrm{~m} \times 1$ m (Hamidah, et.al., 2014), kemudian substrat di sekop sedalam $50 \mathrm{~cm}$ (Murniati,2010). Semua kepiting yang berada dalam transek diambil dan catat titik koordinatnya pada setiap sub-stasiun penelitian.

Sampel yang telah di dapat diawetkan dengan formalin, selanjutnya disimpan dalam toples yang berisi label. Lalu sampel akan diteliti jenisnya di Laboratorium Ilmu Kelautan Fakultas Kelautan Dan Perikanan Universitas Udayana dengan menggunakan buku identifiksi kepiting Uca sp.

\subsubsection{Pengambilan Dan Analisis Parameter} Substrat

Substrat diambil dengan menggunakan sekop sebanyak $1 / 2 \mathrm{~kg}$ pada setiap lokasi penelitian lalu dimasukkan ke plastik yang berisi label.

Selanjutnya sampel dibawa ke Laboratorium Tanah Fakultas Pertanian Universitas Udayana untuk dianalis. Metode yang digunakan untuk analisis substrat adalah metode pipet.

Langkah pertama yang dilakukan dari Langkah pertama yang dilakukan dari metode pipet, yaitu menimbang tanah yang telah dikeringkan sebanyak 20gram, lalu dimasukkan ke erlemeyer $50 \mathrm{ml}$. Selanjutnya ditambahkan air sebanyak 15 ml dan $\mathrm{H}_{2} \mathrm{O}_{2} \quad 30 \%$ sebanyak $15 \mathrm{ml}$ kemudian dikocok memutar dengan tangan. Selanjutnya ditempatkan diatas pemanas dengan suhu rendah dengan menambahkan $\mathrm{H}_{2} \mathrm{O}_{2} \quad 30 \%$. Jika tanah mengandung $\mathrm{CaCO}_{3}$ bebas, maka ditambahkan Hcl 0,4 N sebanyak $45 \mathrm{ml}$ lalu didihkan selama 60 menit, selanjutnya dibiarkan mengendap dan lakukan dekantasi. Tambahkan air sebanyak \pm $300 \mathrm{ml}$ kemudian ditempatkan diatas pemanas dengan menaikkan suhu secara perlahan-lahan dan didihkan selama 1 jam (untuk menghilangkan sisa $\mathrm{H}_{2} \mathrm{O}_{2}$ ), setelah itu didinginkan. Setelah dingin ditambahkan larutan $\mathrm{Na}_{4} \mathrm{P}_{2} \mathrm{O}_{7} 5 \%$ sebanyak $25 \mathrm{ml}$, selanjutnya mixer selama 5 menit, lalu dipisahkan pasir dengan menggunakan ayakan 0,053 $\mathrm{mm}$. Tahap selanjutnya pasir di oven dengan suhu $105^{\circ} \mathrm{C}$ sampai konstan. Tahap akhir yaitu menentukan debu dan liat dengan menggunakan segitiga tekstur.

\subsection{Metode Analisis Data}

\subsubsection{Kepadatan}

Kepadatan adalah jumlah individu per satuan luas (Brower dan Zar, 1977), dengan rumus sebagai berikut: 


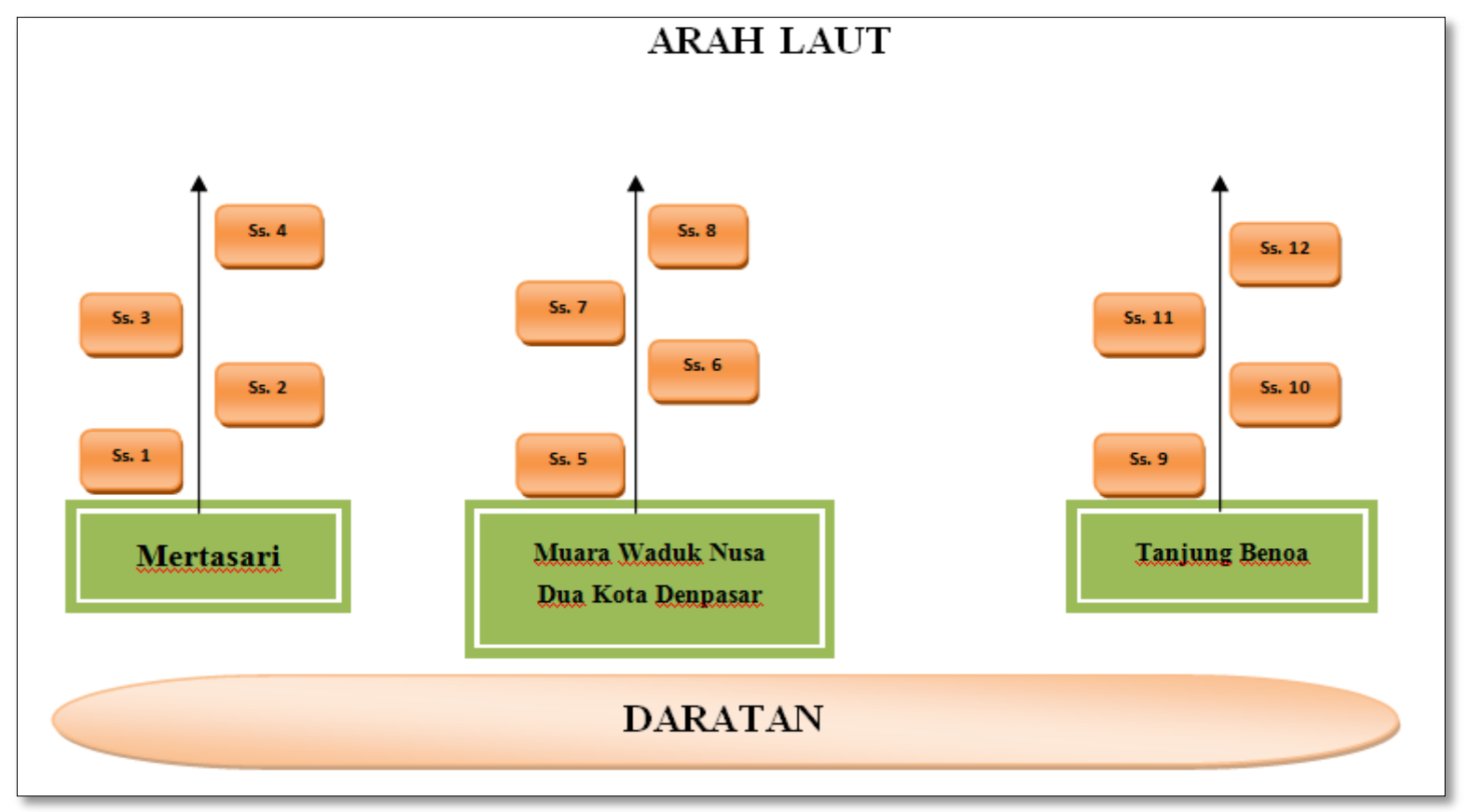

Gambar 2. Titik stasiun dan sub-stasiun pengambilan data

$D i=\frac{n i}{A}$

dimana $\mathrm{D}$ adalah kepadatan kepiting(ind $\left./ \mathrm{m}^{2}\right)$; $\mathrm{Ni}$ adalah jumlah individu (ind); dan $\mathrm{A}$ adalah luas petak pengambilan contoh $\left(\mathrm{m}^{2}\right)$.

\subsubsection{Keanekaragaman $\left(\mathrm{H}^{\prime}\right)$}

Pengolahan data keanekaragaman digunakan indeks Shannon Wiener (Kreb, 2014) dengan rumus sebagai berikut :

\section{$\mathrm{H}^{\prime}=-\sum_{i=1}^{S} \mathrm{Pi} \ln \mathrm{Pi}$}

dimana $\mathrm{H}^{\prime}$ adalah indeks keanekaragaman Shannon Wiener; Pi adalah rasio antara jumlah individu spesies-i (ni) dengan jumlah individu dalam komunitas $(\mathrm{N})$; dan $\mathrm{S}$ adalah jumlah spesies yang menyusun komunitas.

Kriteria hasil keanekaragaman $\left(\mathrm{H}^{\prime}\right)$ menurut Brower dan Zar (1977) adalah sebagai berikut: $\mathrm{H}^{\prime}<$ 1,5 merupakan keanekaragaman jenis rendah; 1,5< $\mathrm{H}^{\prime}<3,5$ merupakan keanekaragaman jenis sedang; dan $\mathrm{H}^{\prime}>$ 3,5 merupakan keanekaragaman jenis tinggi.

\subsubsection{Keseragaman (E)}

Menurut Krebs (2014), indeks keseragaman yang sering digunakan berdasarkan rumus:
$\mathrm{E}=\frac{H^{\prime}}{H_{M A X}}$

dimana E adalah indeks keseragaman ; $\mathrm{H}^{\prime}$ adalah indeks keanekaragaman; HMAx adalah nilai maksimum dari $\mathrm{H}^{\prime}=\log _{2} \mathrm{~S}$

Dengan kriteria sebagai berikut : $0<\mathrm{E} \leq 0,5$ merupakan komunitas tertekan atau keseragaman rendah; 0,5 $<\mathrm{E} \leq 0,75$ merupakan komunitas labil atau keseragaman sedang; dan 0,75< $\mathrm{E} \leq 1$ merupakan komunitas stabil atau keseragaman tinggi.

\subsubsection{Dominansi (D)}

Untuk mengetahui ada tidaknya dominansi dari spesies tertentu digunakan Indeks Dominan Simpson (Brower dan Zar, 1977), yaitu :

$\mathrm{D}=\sum_{i=1}^{S}(p i)^{2}=\sum_{i=1}^{S}(n i / N)^{2}$

dimana D adalah indeks dominansi; ni adalah jumlah individu spesies ke-I; $\mathrm{N}$ adalah jumlah total individu; dan s adalah jumlah spesies.

Nilai indeks dominansi berkisar antara 0 - 1 . Jika indeks dominansi mendekati 0 , berarti hampir tidak ada individu yang mendominasi dan biasanya diikuti dengan indeks keseragamanan yang besar. Apabila indeks dominansi mendekati 1, berarti ada salah satu genera (genus) yang mendominasi dan nilai indeks keseragaman semakin kecil (Odum, 1971). 


\section{Hasil dan Pembahasan}

\subsection{Hasil}

\subsubsection{Komposisi Jenis Uca sp Berdasarkan Karakteristik Substrat}

Berdasarkan hasil penelitian pada 3 stasiun, dimana setiap sub-stasiun memiliki komposisi jenis Uca sp yang berbeda-beda berdasarkan karakteristik substrat. Pada substrat pasir ditemukan jenis paling banyak yaitu Uca cryptica sebanyak $65 \%$, diikuti oleh Uca crassipes sebanyak $30 \%$ dan terendah Uca vomeris sebanyak $5 \%$. Pada substrat pasir berlempung ditemukan dua jenis Uca sp yaitu Uca vomeris sebanyak $83 \%$ dan Uca cryptica sebanyak $17 \%$. Pada substrat lempung berpasir hanya ditemukan satu jenis Uca $s p$ yaitu Uca rosea.

Berdasarkan hasil penelitian pada 3 stasiun, dimana setiap stasiun memiliki komposisi jenis Uca sp yang berbeda-beda. Pada stasiun 1 paling banyak ditemukan Uca vomeris sebanyak $78 \%$ yang diikuti oleh Uca cryptica sebanyak $18 \%$ dan Uca dussumieri sebanyak 4\%. Pada stasiun 2 hanya ditemukan satu jenis Uca yaitu Uca rosea. Sedangkan pada stasiun 3 ditemukan dua jenis Uca yaitu Uca cryptica sebanyak $69 \%$ yang paling banyak ditemukan dan Uca crassipes sebanyak $31 \%$.

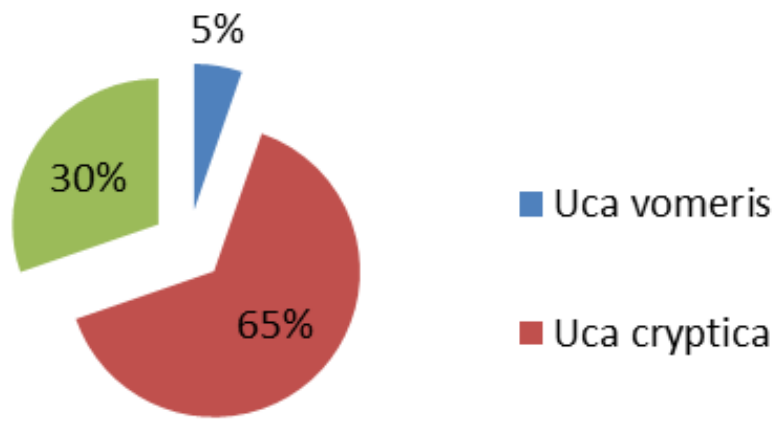

Gambar 3. Komposisi jenis Uca $s p$ pada karakteristik substrat pasir

\subsubsection{Kepadatan Uca sp pada 3 kawasan mangrove} yang berbeda

Berdasarkan hasil pengumpulan data pada 3 kawasan mangrove yang berbeda didapatkan hasil rata-rata kepadatan $U_{c a} s p$ pada setiap stasiun berbeda, dimana kepadatan tertinggi ada pada stasiun 2 yang terletak di Muara Waduk Nusa Dua Kota Denpasar didapatkan 52,75 ind $/ \mathrm{m}^{2}$, diikuti oleh stasiun 1 yang terletak di Mertasari didapatkan $45 \mathrm{ind} / \mathrm{m}^{2}$ dan terendah pada stasiun 3 yang berada di Tanjung Benoa didapatkan 32,25 ind $/ \mathrm{m}^{2}$. Grafik hasil kepadatan terhadap Uca $s p$ dapat dilihat pada Gambar 6.

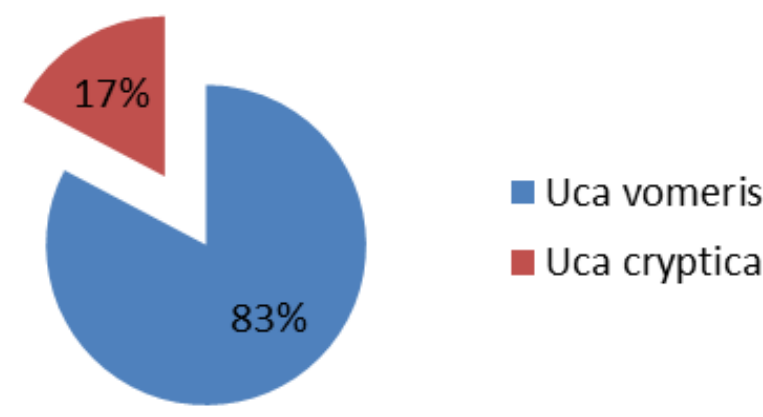

Gambar 4. Komposisi jenis Uca sp pada karakteristik substrat pasir berlempung

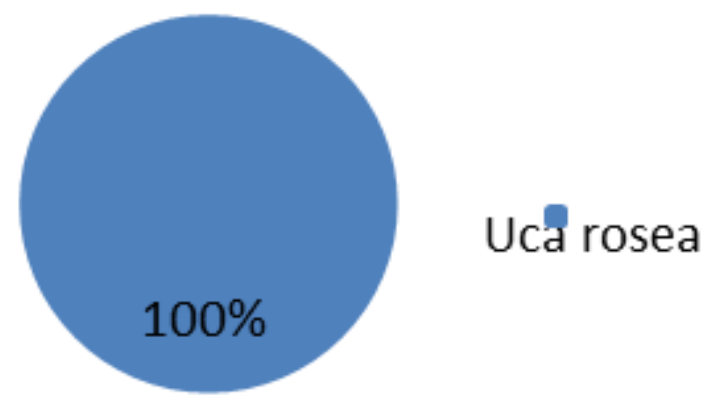

Gambar 5. Komposisi jenis Uca $s p$ pada karakteristik substrat lempung berpasir

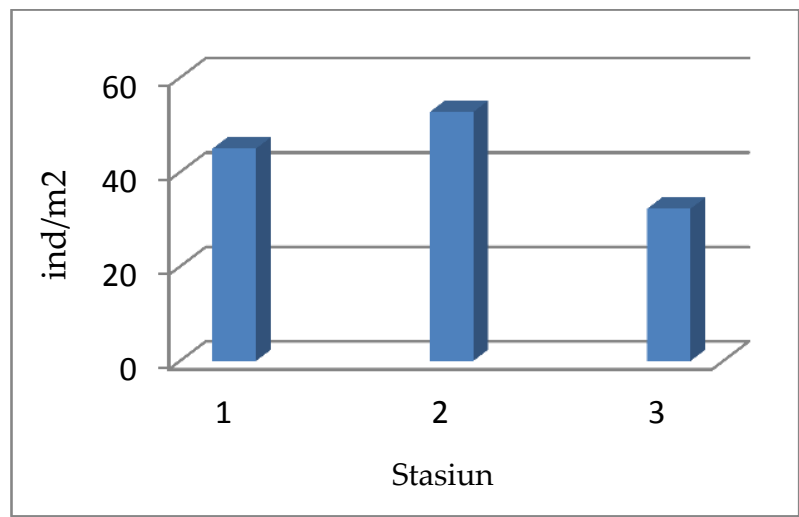

Gambar 6. Grafik kepadatan Uca sp pada 3 stasiun kawasan mangrove yang berbeda

3.1.3 Keanekaragaman Uca sp pada 3 kawasan mangrove yang berbeda

Nilai indeks keanekaragaman $U_{c a} s p$ pada 3 stasiun dikawasan mangrove yang berbeda menunjukkan bahwa stasiun 2 paling rendah nilai indeks keanakaragaman dibandingkan dengan stasiun 1 dan 3 . Pada stasiun 1 yang berlokasi di 
Mertasari sebesar 0,6246, stasiun 2 yang berlokasi di Muara Waduk Nusa Dua Kota Denpasar sebesar 0 dan stasiun 3 yang berlokasi di Tanjung Benoa sebesar 0,6192. Grafik hasil keanekaragaman terhadap Uca sp dapat dilihat pada Gambar 7.

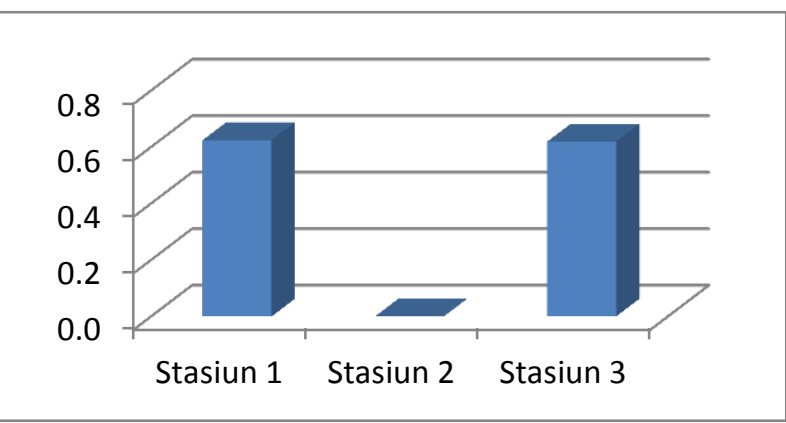

Gambar 7. Grafik keanekaragaman Uca sp pada 3 stasiun kawasan mangrove yang berbeda

3.1.4 Keseragaman Uca sp pada 3 kawasan mangrove yang berbeda

Berdasarkan hasil pengumpulan data selama penelitian pada 3 kawasan mangrove yang berbeda, pada stasiun 1 yang berlokasi di Mertasari didapatkan keseragaman tertinggi sebesar 0,3881, selanjutnya diikuti oleh stasiun 3 yang berlokasi di Tanjung Benoa didapatkan keseragaman sebesar 0,3847. Dan keseragaman terendah pada stasiun 2 yang berlokasi di Muara Waduk Nusa Dua Kota Denpasar didapatkan keseragaman sebesar 0. Grafik hasil keseragaman terhadap Uca sp dapat dilihat pada Gambar 8.

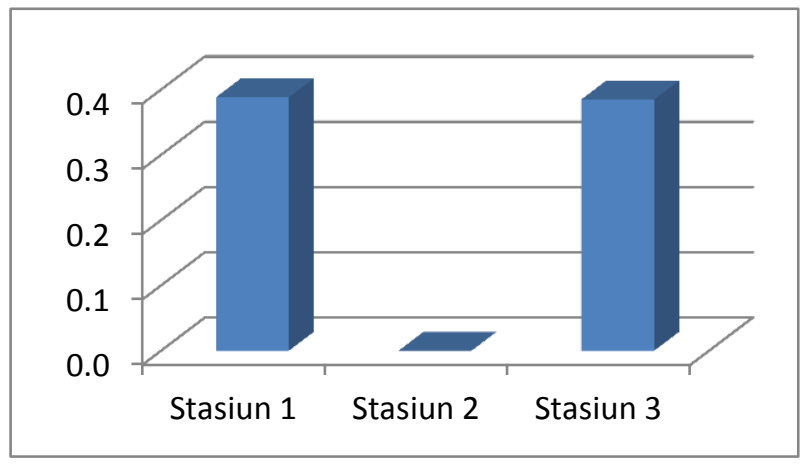

Gambar 8. Grafik keseragaman Uca sp pada 3 stasiun kawasan mangrove yang berbeda

3.1.5 Dominansi Uca sp pada 3 kawasan mangrove yang berbeda

Dominansi Uca sp pada 3 kawasan mangrove yang berbeda didapatkan hasil indeks dominansi tertinggi sebesar 1 pada stasiun 2 yang berlokasi di Muara Waduk Nusa Dua Kota Denpasar, kemudian diikuti oleh stasiun 1 yang berlokasai di Mertasari sebesar 0,6467 dan terendah pada stasiun 3 yang berlokasi di Tanjung Benoa sebesar 0,5721. Grafik hasil dominansi terhadap Uca $s p$ dapat dilihat pada Gambar 9.

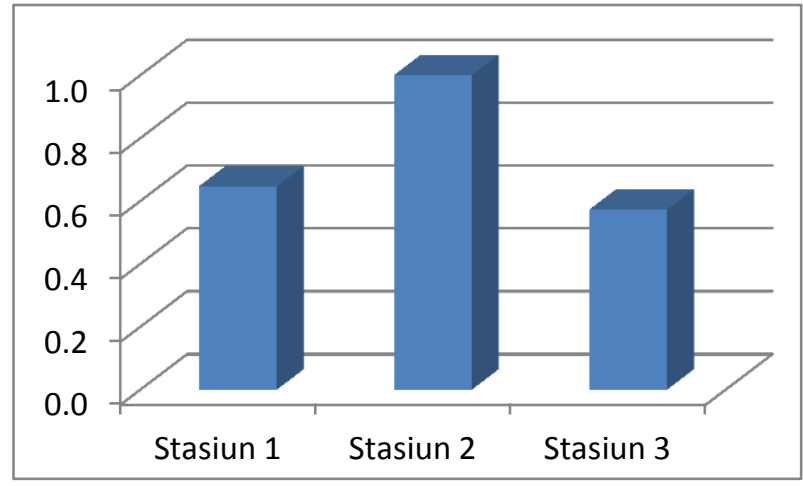

Gambar 9. Grafik dominansi Uca $s p$ pada 3 stasiun kawasan mangrove yang berbeda

\subsection{Pembahasan}

Spesies yang didapat selama penelitian di 3 kawasan lokasi penelitian yaitu sebanyak 5 spesies, antara lain Uca vomeris, Uca cryptica, Uca dussumieri, Uca rosea dan Uca crassipes. Pada substrat pasir ditemukan spesies yang paling banyak yaitu Uca cryptica, Uca crassipes dan Uca vomeris. Pada substrat pasir berlempung ditemukan spesies Uca vomeris dan Uca cryptica. Pada substrat lempung berpasir hanya ditemukan satu spesies yaitu Uca rosea.

Tekstur tanah ekosistem mangrove yang berbeda mempengaruhi fauna makrobentos didalamnya. Substrat merupakan faktor lingkungan yang terpenting bagi kehidupan Uca sp, sebab substrat merupakan habitat berpijah (spawning ground), mencari makan (feeding ground) dan habitat asuh (nursery ground). Berdasarkan analisis di Laboratorium dimana pada stasiun 1 memiliki karakteristik substrat pasir berlempung, namun pada sub-stasiun 1 memiliki tekstur substrat yang berbeda yaitu substrat pasir. Hal ini dikarenakan pada sub-stasiun 1 paling jauh dari pantai dan lebih dekat kearah daratan, dan ditemukan spesies Uca vomeris dan Uca cryptica. Menurut penelitian Murniati (2010) yang menyatakan bahwa Uca cryptica hidup di substrat berpasir. Sub-stasiun 2 dan 3 memiliki tekstur substrat pasir berlempung ditemukan spesies Uca vomeris. Uca vomeris yang ditemukan di daerah Bali 
hidup disubstrat pasir berlempung. Menurut Murniati (2010) yang menyatakan bahwa Uca vomeris hidup disubstrat berlumpur. Meskipun tekstur substrat sedikit berbeda tetapi masih terdapat kandungan liat yang memungkinkan Uca vomeris dapat hidup. Sub-stasiun 4 memiliki tekstur substrat pasir berlempung ditemukan spesies Uca vomeris dan Uca dussumieri. Menurut penelitian Suprayogi, et.al (2014) yang menyatakan bahwa Uca dussumieri lebih selektif terhadap substrat, karena hanya dapat hidup pada substrat yang dominan dari fraksi pasir (82,36\%).

Stasiun 2 memiliki karakteristik substrat yang didominansi oleh substrat lempung berpasir, dimana pada sub-stasiun 8 memiliki karakteristik substrat paling berbeda yaitu lempung liat berpasir. Lokasi sub-stasiun 8 lebih banyak terkena genangan air, maka dari itu karakteristik substratnya lebih berbeda dengan sub-stasiun lainnya di stasiun 2, spesies yang ditemukan yaitu Uca rosea, menurut Arsana (2010) yang menyatakan bahwa pada umumnya Uca sp hidup berkelompok pada habitat lumpur atau pasir. Jenis Uca sp yang hidup di lumpur berbeda dengan jenis yang hidup di pasir. Dalam satu habitat dapat dihuni oleh 2 - 5 jenis, namun masing-masing jenis menempati mikrohabitat yang berbeda. Substasiun 5, 6 dan 7 memiliki tekstur substrat yang sama yaitu lempung berpasir ditemukan spesies Uca rosea, berdasarkan penelitian Hamidah et.al. (2014) yang menyatakan bahwa Uca rosea hidup di substrat liat dan lempung berpasir dikarenakan Uca rosea merupakan spesies Uca sp yang jenisnya banyak di jumpai dikawasan mangrove dan jenis substrat ini menyebabkan Uca sp lebih bervariasi. Uca rosea memiliki ukuran lebih kecil dibandingkan dengan Uca sp lainnya, dimana ukuran capitnya yang kecil menyebabkan lebih susah untuk menggali substrat yang keras. Maka dari itu Uca rosea lebih banyak ditemukan pada stasiun 2.

Stasiun 3 memiliki karakteristik substrat yang didominansi pasir, dimana pada sub-stasiun 12 memiliki karakteristik substrat paling berbeda yaitu pasir berlempung, spesies yang ditemukan hanya Uca crpytica, berdasarkan penelitian Murniati (2010) yang menyatakan bahwa Uca crpytica hidup di substrat berpasir. Walaupun jenis substrat yang ditemukan berbeda dengan penelitan Murniati (2008), tetapi Uca cryptica masih dapat hidup disubstrat pasir berlempung, hal ini diduga karena masih ada kandungan pasir di dalamnya. Pada sub-stasiun 9, 10 dan 11 memiliki tekstur substrat pasir ditemukan spesies Uca crpytica dan Uca crassipes. Diduga substrat pasir lebih disukai Uca sp dan substrat tersebut dapat mempermudah kedua spesies Uca $s p$ ini dalam membuat lubang. Pernyataan tersebut didukung oleh penelitian Suprayogi, et.al., 2014 yang menyatakan bahwa substrat pasir mempermudah kedua spesies tersebut untuk membuat lubang.

Kepadatan Uca sp berdasarkan spesies yang ditemukan di 3 kawasan mangrove yang berbeda, dimana kepadatan tertinggi ditemukan pada stasiun 2 yang terletak di Muara Waduk Nusa Dua Kota Denpasar dan kepadatan terendah pada stasiun 3 yang terletak di Tanjung Benoa. Kepadatan Uca sp tertinggi pada stasiun 2 diduga karena kondisi lingkungan tempat hidupnya sesuai untuk spesies tersebut dan disekitar mangrove kawasan Muara Waduk Nusa Dua Kota Denpasar banyak terdapat serasah mangrove karena lokasi ini tertutup dari perairan terbuka, sehingga sirkulasi air yang terjadi saat pasang surut sangatlah kecil yang mengakibatkan serasah tidak terbawa arus pasang surut. Pernyataan tersebut didukung oleh penelitian Suprayogi, et.al. (2014) yang menyatakan bahwa kondisi lingkungan sesuai akan memungkinkan produksi serasah lebih banyak, sehingga memiliki jumlah detritus yang tinggi.

Pada stasiun 3 nilai kepadatannya rendah diduga lingkungan hidupnya kurang sesuai karena kondisi lingkungan mangrove yang dekat dengan perairan terbuka yang mengakibatkan serasah mangrove terbawa arus pasang surut, sehingga produksi serasah mangrove lebih sedikit jika dibandingkan dengan stasiun 2. Hal ini didukung oleh penelitian Murniati (2008) yang menyatakan bahwa semakin tinggi produksi serasah yang dihasilkan oleh mangrove, maka Uca $s p$ lebih mudah mendapatkan makanan sehingga mempengaruhi tinggi rendahnya kepadatan Uca sp. Begitupula dengan penelitian Suprayogi, et.al. (2014) yang menyatakan bahwa Uca sp sebagai makrobhentos sangat peka terhadap perbedaan kondisi lingkungnnya seperti pasang surut, sehingga berpengaruh terhadap komposisi dan kelimpahannya.

Hasil perhitungan dengan rumus indeks keanekaragaman jenis yang dilakukan menghasilkan data bahwa keanekaragaman jenis pada ketiga stasiun tergolong keanekaragaman rendah, karena $\mathrm{H}^{\prime}<1,5$. Menurut Natania, et.al. 
(2017) menyatakan bahwa rendahnya keanekaragaman pada ketiga stasiun ini menunjukkan komunitas memiliki kompleksitas rendah, karena dalam komunitas tidak banyak terjadi interaksi antar jenis. Komunitas dengan keanekaragaman jenis rendah, sedikit terjadi interaksi antar jenis yang melibatkan transfer energi, predasi dan kompetisi. Odum (1971) menjelaskan keanekaragaman jenis cenderung rendah dalam ekosistem yang secara fisik terkendali (sasaran faktor pembatas fisika kimia yang kuat). Keanekaragaman rendah adanya jenis yang ditemukan di lokasi penelitian sedikit. Menurut Zulkifli dan Setiawan (2011), menyatakan bahwa keanekaragaman ditandai dengan banyaknya spesies yang membentuk komunitas baru semakin banyak jumlah spesies maka semakin tinggi keanekaragaman.

Pada ketiga stasiun penelitian dikategorikan kedalam indeks keseragaman dengan komunitas tertekan atau keseragaman rendah. Hal ini dikarenakan jumlah masing-masing spesies yang ditemukan pada tiap stasiun berbeda-beda terutama pada stasiun 2 memiliki jumlah spesies yang paling tinggi. Selain itu, juga diduga karena perbedaan jenis substrat pada tiap stasiun yang berbeda-beda yang mengakibatkan jumlah masing-masing spesies yang didapatkan juga berbeda. Sesuai hasil penelitian yang dilakukan oleh Kreb, 1989 in Natania, et al. (2017), keseragaman populasi akan kecil jika nilai keseragaman semakin kecil, yang artinya penyebaran jumlah individu setiap jenisnya tidak sama dan ada kecenderungan satu jenis tertentu mendominasi populasi tersebut. Semakin tinggi penyebaran individu antar spesies, maka keseimbangan ekosistem akan makin meningkat.

Berdasarkan perhitungan pada ketiga stasiun tersebut mempunyai indeks dominansi tinggi. Apabila indeks dominansi mendekati 1, berarti ada salah satu genera (genus) yang mendominasi dan nilai indeks keseragaman semakin kecil (Odum, 1971). Pada stasiun 2 spesies Uca sp yang paling banyak ditemukan yaitu Uca rosea, hal ini diduga karena Uca rosea memiliki kemampuan beradaptasi yang baik pada substrat tersebut dan disekitar mangrove kawasan Muara Waduk Nusa Dua Kota Denpasar banyak terdapat serasah mangrove yang digunakan Uca sp sebagai makanannya. Menurut Natania, et.al. (2017), menyatakan bahwa apabila indeks dominansi tinggi, maka dominansi (penguasaan) terpusat (terdapat) pada satu spesies.
Tetapi apabila nilai indeks dominansi rendah, maka dominansi terpusat (terdapat) pada beberapa spesies. Tidak adanya spesies Uca $s p$ yang mendominansi di ekosistem mangrove tersebut menunjukan bahwa perairan tersebut cukup sesuai untuk kehidupan Uca sp.

\section{Simpulan}

Berdasarkan hasil penelitian yang telah dilakukan, maka dapat disumpulkan bahwa jenis Uca sp yang ditemukan sebanyak 5 jenis, diantaranya Uca cryptica, Uca dussumieri, Uca rosea, Uca cryptica dan Uca crassipes. Pada stasiun 1 ditemukan Uca vomeris yang ditemukan disubstrat pasir berlempung, Uca cryptica yang ditemukan di substrat berpasir dan Uca dussumieri ditemukan disubstrat pasir berlempung. Pada stasiun 2 hanya ditemukan Uca rosea yang ditemukan disubstrat lempung berpasir dan pada stasiun 3 ditemukan Uca cryptica dan Uca crassipes yang ditemukan disubstrat berpasir. Kepadatan Uca sp pada stasiun 1 sebanyak $45 \mathrm{ind} / \mathrm{m}^{2}$ yang ditemukan pada substrat pasir berlempung, stasiun 2 sebanyak $52,75 \mathrm{ind} / \mathrm{m}^{2}$ yang ditemukan pada substrat lempung berpasir dan stasiun 3 sebanyak 32,25 ind $/ \mathrm{m}^{2}$ yang ditemukan pada substrat berpasir. Dari ketiga stasiun didapatkan hasil bahwa nilai indeks keanekaragaman jenis tergolong keanekaragaman rendah, sedangkan nilai keseragaman dikategorikan komunitas tertekan atau keseragaman rendah dan nilai indeks dominansi dikategorikan dominansi tinggi.

\section{Daftar Pustaka}

Arsana, I. N. (2010). Struktur popolasi kepiting Uca triangularis di pantai serangan, Bali. Widya Biologi, 1(1), 18-25.

Brower, J. E., \& Zar, J. H. (1977). Field and Laboratory Method for Generall Ecology. Debuque. Iowa, USA: Wm, C Brown Publ.

Faiqoh, E., Hayati, H., \& Yudiastuti, K. (2016). Studi Komunitas Makrozoobenthos di Kawasan Hutan Mangrove Pulau Penyu, Tanjung Benoa, Bali. Journal of Marine and Aquatic Sciences, 2(1), 23-28.

Hamidah, A., Fratiwi, M., \& Siburian, J. (2014). Kepadatan Kepiting Biola (Uca spp.) Jantan dan Betina di Desa Tungkal I Tanjung Jabung Barat. Penelitian Universitas Jambi Seri Sains, 16(2), 43- 50.

Hamidy, R (2010). Struktur Dan Keragaman Komunitas Kepiting Di Kawasan Hutan Mangrove Stasiun Kelautan Universitas Riau, Desa Purnama Dumai. Ilmu Lingkungan, 2(4), 81-91. 
Husnah, H., Prianto, E., \& Aida SN. (2017). Kualitas Perairan sungai Musi Bagian Hilir Ditinjau Dari Karakteristik Fisika-Kimia Dan Struktur Komunitas Makrozoobenthos. Penelitian Perikanan Indonesia, 13(3), 167-177.

Krebs, C. J. (2014). Ecologycal Methodology. University of British. ( $3^{\text {rd }}$ ed.). Columbia, USA: Addison-Wesley Educational Publishers. Inc.

Lailvaux, S. P., Reaney, L. T., \& Backwell, P. R. (2009). Dishonest signalling of fighting ability and multiple performance traits in the fiddler crab Uca mjoebergi. Functional Ecology, 23(2), 359-366.

Majid, I., Al Muhdar M. H. I., Rohman F., \& Syamsuri, I. (2016). Konservasi Hutan Magrove Di Pesisr Pantai Kota Ternate Terintegrasi Dengan Kurikulum Sekolah. Bioedukasi, 4(2), 488-496.

Mulyanto, M., \& Umi, H. (2017). The Effects of Fiddler Crabs (Uca sp) on C/N Ratio and Redox Potential of Soil in Mangrove Ecosystems. Research Journal of Life Science, 3(2), 129-136.

Murniati, D. C. (2008). Uca lactea (DE HAAN, 1835) (DECAPODA; CRUSTACEAE) Kepiting Biola Dari Mangrove. Fauna Indonesia, 8(1), 14- 17.

Murniati, D. C. (2010). Keanekaragaman Uca spp Dari Sagara-Anakan, Cilacap, Jawa Tengah Sebagai Pemakan Deposit. Fauna Indonesia, 9(1), 19-23.
Natania, T., Herliany, N. E., Kusuma, A. B. (2017). Struktur Komunitas Kepiting Biola (Uca spp.) Di Ekosistem Mangrove Desa Kahyapu Pulau Enggano. Enggano 2(1), 24-36.

Odum, E. P. (1971). Fundamentals of Ecology. (3 ${ }^{\text {rd }}$ ed). Philadelphia, USA: W.B. Saunders Co.

Pratiwi, R. (2009). Komposisi Keberadaan Krustasea di Mangrove Delta Mahakam Kalimantan Timur. Makara 13(1), 65-76.

Rauf, A., Kasim, A., Ramadhan, A. (2016). Struktur Komunitas Kepiting di Hutan Mangrove Kecamatan Toribulu Kabupaten Parigi Moutong Dan Pemanfaatannya Sebagai Media Pembelajaran Biologi. Jurnal Sains dan Teknologi Tadulako, 5 (1), 22-32.

Supraygogi, D., Siburian, J., \& Hamidah, A. (2014). Keanekaragaman Kepiting Biola (Uca spp.) di desa Tungkal I Tanjung Jabung Barat. Biospecies, 7(1), 22-28.

Warsidi, Endayani, S. (2017). Komposisi Vegetasi Mangrove Di Teluk Balikpapan Provinsi Kalimantan Timur. AGRIFOR 16(1), 115-124.

Zulkifli, H., \& Setiawan, D. (2011). Struktur Komunitas Makrozoobentos di Perairan Sungai Musi Kawasan Pulokerto sebagai Instrumen Biomonitoring. Natur Indonesia 14(1), 95-99.

(C) 2017 by the authors; licensee Udayana University, Indonesia. This article is an open access article distributed under the terms and conditions of the Creative Commons Attribution license (http://creativecommons.org/licenses/by/3.0/). 